\title{
Pandemi Sürecinin Toplu Taşıma Türlerine Yönelik Etkisinin Ölçülmesi: Çok Terimli Logit Bağlanım Modeli, İstanbul Örneği
}

\author{
Enver Cenan İnce ${ }^{1}$ \\ ORCID: 0000-0002-8264-6707
}

\author{
Elif Can Cengiz ${ }^{2}$ \\ ORCID: 0000-0002-7720-5966
}

\author{
Pelin Alpkökin ${ }^{3}$ \\ ORCID: 0000-0002-9612-2023
}

\section{Öz}

Pandemi sürecinde kentsel topluluklarm temel gereksinimleri kapsamında ev bazlı iş ile ev bazlı zaruri alışveriş yolculukları gibi zorunlu kentsel hareketliliklerin sağlanmasına yönelik kentsel ulaşım talebinin toplu taşıma hizmet ayă̆ının yeniden sorgulanması konusu, sıkça üzerinde durulan konulardan biri haline gelmiştir. Bu bağlamda, özellikle toplu taşıma hizmeti sağlayan yüksek yolcu taşıma kapasiteli taşıtların, virüsün hızla yayılması için verimli bir ortam yarattığına yönelik yaygın düşüncenin, yolculuk türel dağılımlarında toplu taşıma kullanım oranlarının aleyhine olacak bir biçimde ciddi değişimlere yol açtı̆̆ı gözlemlenmektedir. Bu noktadan hareketle ortaya konulan bu çalışmada, İstanbul içerisinde aktif olarak kullanılan toplu taşıma türlerindeki kullanım oranlarının pandemi sürecinden etkilenme düzeyleri, çok terimli logit bağlanım modeli aracılığıyla deneysel olarak ortaya konulmuştur. Elde edilen model bulgularna göre, İstanbul'da pandemi sürecinin etkisiyle otobüs, metrobüs, metro, hafif raylı sistemler, Marmaray ve deniz ulaşımı türlerinin kullanımı \% 43 ile \% 24 arasında değişen oranlarda azalış göstermiş olup, söz konusu dalgalanmaların yolculuk talepleri ve taşıma kapasiteleri ile doğru orantıl olarak şiddetlendiği görülmüş̧ür.

Anahtar Kelimeler: Pandemi ve Ulaşım, Pandemi ve Toplu Taşıma, Çok Terimli Logit Bă̆lanım Modeli.

\footnotetext{
${ }^{1}$ Dr. Öğr. Üyesi, Sivas Cumhuriyet Üniversitesi, E-mail: eince@cumhuriyet.edu.tr

${ }^{2}$ Dr., Avrasya Consult, Marmaray Projesi, E-mail: elifcanyuce@gmail.com

${ }^{3}$ Doç. Dr., İstanbul Teknik Üniversitesi, İstanbul Büyükşehir Belediyesi,

E-mail: pelin.alpkokin@ibb.gov.tr

idealkent @ Kent Araştırmaları Dergisi (Journal of Urban Studies)

http://idealkentdergisi.com

Geliş Tarihi Received Date: 30.09.2021 Kabul Tarihi Accepted Date: 27.12.2021
} 


\title{
Measuring the Effect of Pandemic on Public Transportation Modes: Multinominal Logit Model in İstanbul
}

\author{
Enver Cenan İnce ${ }^{1}$ \\ ORCID: 0000-0002-8264-6707
}

\author{
Elif Can Cengiz ${ }^{2}$ \\ ORCID: 0000-0002-7720-5966
}

\author{
Pelin Alpkökin ${ }^{3}$ \\ ORCID: 0000-0002-9612-2023
}

\begin{abstract}
The precautions of the pandemic process has resulted in the investigations on the changes of basic requrements of the urban communities with especially regard to the imperative urban motorized flows called home based work trips and home based imperative shopping trips, which are carried out by urban public transportation facilities. In this sense, the decrease in the usage of the public transportation modes -with regard to the common belief indicating that the pandemic virus generally sprawls in the public transport modes with high passenger carriage capacities- has extensively begun to be interrogated. From this point forth, this article measured the effect of the pandemic on the modal split ratios in the usage of public transport modes with the help of multinominal logistic regression model. According to the findings, the decrease -changing in between $24 \%$ and $43 \%$ in the usage of the public transportation modes called bus, metrobus, metro, light rail systems, Marmaray, and sea transport- was observed. Also, it was seen that the related decreasing ratios got larger as the passenger carrying capacities of the public transit mode increased.
\end{abstract}

Keywords: Pandemic and Transportation, Pandemic and Public Transport, Multinominal Logistic Regression Model.

\footnotetext{
${ }^{1}$ Asst.Prof.Dr., Sivas Cumhuriyet University, E-mail: eince@cumhuriyet.edu.tr

${ }^{2}$ Dr., Avrasya Consult, Marmaray Project, E-mail: elifcanyuce@gmail.com

${ }^{3}$ Assoc.Prof. Dr., İstanbul Technical University, İstanbul Metropolitan Municipality,

E-mail: pelin.alpkokin@ibb.gov.tr

idealkent (c) Kent Araştırmaları Dergisi (Journal of Urban Studies)

http://idealkentdergisi.com

Geliş Tarihi Received Date: 30.09.2021 Kabul Tarihi Accepted Date: 27.12.2021
} 


\section{Giriş}

Bulaşıcı ve salgın hastalıklar kapsamında değerlendirilen COVID-19 salgını, küreselleşmenin ve insan hareketliliğinin etkisiyle çok kısa bir sürede tüm dünyayı etkisi altına almış ve küresel bir krize dönüşmüştür (DSÖ, 2020; Tavukçu, 2020). Bu yüzden tüm ülkeler ilk olarak insan hareketliliğini sinırlandırarak hastalığın yayılımını yavaşlatma çabasına girmiştir. Söz konusu çaba ise, kentsel ulaşım hareketliliklerinde ciddi değişikliklere yol açmıştır ve söz konusu değişikliklerin deneysel olarak ölçülmesi, sürecin yarattı̆̆ olumsuzlukların giderilmesi için elzem olmuştur.

Söz konusu temel motivasyondan hareketle bu çalışmada, Haziran 2019, Temmuz 2020 ve Mayıs 2021 tarihlerine yönelik İstanbul Büyükşehir Belediyesi'nce yayımlanan detaylı yolculuk verileri (IBBB, 2019; 2020; 2021) üzerinden kurulan Çok Terimli Logit Bağlanım Modeli (ÇTLBM) aracılığıyla ortaya konulan bulgular üzerinden pandemi sürecinin de etkisiyle İstanbul özelindeki yolculuk türel dağılımlarının ne yönde değiştiği tartışılmıştır. Bu noktada, gerek pandemi sürecinin İstanbul özelindeki genel yansımaları gerekse de yolculuk talep eğilimlerindeki değişimlerin daha net bir şekilde takip edilebilmesi adına üç temel konu başlığı belirlenmiştir. Bunlar: "20192020 ve 2021 Toplu Taşıma Verileri ile İstanbul'da ulaşıma COVID-19 Pandemisi'nin Etkileri", "Türkiye'de ulaşım alanında alınan önlemler" ve "Al1nan önlemlerin İstanbul toplu taşımasına yansımaları" şeklindedir.

İlk olarak, COVID-19 salgınına yönelik ilk vakanın görüldüğü tarih olan Aralık 2019'dan itibaren söz konusu salgın tüm dünyayı etkisi altına almış olup, bu çalışmanın yapıldığı 4 Ağustos 2021 tarihine kadar dünyada 200 milyonun üzerinde vaka tespit edilmiştir. Toplam vaka ve ölüm sayıları bakımından ilk üç sırayı Amerika, Hindistan ve Brezilya almaktadır (Worldometer, 2021). Sağlık Bakanlığı'nın yaptığı açıklamaya göre Türkiye'de 12 Ağustos 2021 tarihinde 281.535 adet test yapılmış ve bu testlerden toplam 22.261 vaka tespit edilmiş olup toplam ölüm sayısı 138 olarak açıklanmış ve bu sayıla beraber Türkiye'de COVID-19 sebebiyle hayatın kaybedenlerin toplam sayısı 52.703 olmuştur (TÜBİTAK, 2021).

2020 yılının başından itibaren pandemi tüm sektörleri ve kentsel toplulukları yakından etkilemiştir. Söz konusu salgın sürecinden sağlık, gıda gibi bazı sektörler olumlu olarak etkilenirken,turizm ve ulaşım gibi sektörler önemli ölçüde olumsuz etkilenmiştir (Gümüş, Hacievliyagil, 2020). Çünkü pandemi kapsamında yönetimlerin aldığı ilk önlem sosyal mesafenin korunması olmuştur. Pandemi öncesinde kentler sürdürülebilir bir ulaşım için 
insanları toplu taşım kullanmaya teşvik etmekteydi. Bunu yaparken de en fazla yolcuyu en az araç ile en etkin ve çevreye en az zararı verecek şekilde yapmaya çalışmaktaydı. Pandemi ile birlikte ise, hareketliliğin azalmasına yönelik evden çalışma ve uzaktan eğitim gibi önlemler tüm dünyada alınmıştır. Kalan hareketliliğin de türel dağılımı kentlerde büyük ölçüde değişikliğe uğramıştır (Sinko, Prah ve Kramberger, 2021).

İtalya'da yapılan bir çalışmada toplu taşıma kullanımının günlük vaka sayılarına doğrudan etkisi olduğu ortaya konulmuştur. Bu durum kapanma ve toplu taşımada alınan çeşitli önlemlerin önemini göstermektedir (Carteni, Di Francesco, Martino, 2020). Felchetta ve Noussan (2020) tarafından yap1lan araştırmada insanların daha maliyetli olmasına rağmen hastalık riskini azaltmak adına günlük ulaşımda toplu taşıma yerine özel araç kullanımına yöneldiği belirtilmektedir (Falchetta ve Noussan, 2020; Christidis, Christodoulou, Navajas-Cawood ve Ciuffo, 2021).

Pandeminin ilk dalgası ile birlikte Almanya'nın Augsburg kenti ile Avusturya'nın Viyana kentinde toplu taşıma kullanıcılarının \%80 azaldığ belirtilmiştir. Benzer şekilde kısıtlamaların kalktığı ve tam kapasite hizmete geçildiği belirtilmesine rağmen Madrid Metrosu ilk gün \%75 daha az yolcu ile çalışmıştır (Bernhardt, 2020).

Pandemi öncesi Almanya'nın Berlin Kenti'nde günlük yolculuklarda özel araç kullanımı, pandemi ile beraber \% 63'ten \% 69'a çıkmıştır. Toplu taşıma kullanımı oranı \% 17'den \% 12'ye düşmüştür. Özellikle uzun mesafe raylı sistem yolculukları oranı \% 13'ten \% 5'e gerilemiştir. Buna karşın söz konusu kentte yürüme ve bisiklet gibi aktif ulaşım türleri kullanım oranları sırasıyla \% 3 ve \% 4 artmıştır. Bu durum, kentsel toplulukların, toplu taşıma türlerini daha az tercih ederek virüs salgınından kaçınma eğiliminde olduğunun bir göstergesi sayılabilir (Amelang, 2020).

Alman Havacılık ve Uzay Merkezi tarafından yapılan bir çalışmada Koronavirüs pandemisinin kentsel toplulukların ulaşım tercihlerini nasıl etkilediği araştırılmıştır. Buna göre insanlar toplu taşımadan çok özel araca yönelmiş ve özel aracın popülerliği artmıştır. Bu durum kentlerde ulaşımın türel dağılımını doğrudan etkilemiştir. Örneğin çalışmada araç sahibi olmayan katılımcıların \% 6'sı araç almayı düşündüğünü, \% 9'u ise bisiklet almayı planladığını söylemiştir (Amelang, 2020).

Ayrıca Ekim 2020 Londra Belediye Başkanı ile yapılan röportajda 2019 yılı kent içi ulaşımda türel dağılım ortalaması ve 2020 yılı ilk iki çeyrek türel dağılım ortalaması aşağıdaki grafikte (Şekil 1) gösterildiği gibidir (London Assembly, 2020). Pandemi öncesi 2018 ve 2019 yıllarındaki dağılım büyük 
benzerlik gösterirken, pandeminin ortaya çıktığı 2020 yılının ilk yarısında ise büyük değişiklikler izlenmiştir. Toplu taşımanın bu denli azalıp özel araç kullanımının artması, Londra kentinde desteklenen etkin ve sürdürülebilir bir ulaşım sistemi oluşturulması amacından uzaklaşıldığını göstermektedir (London Assembly, 2020).

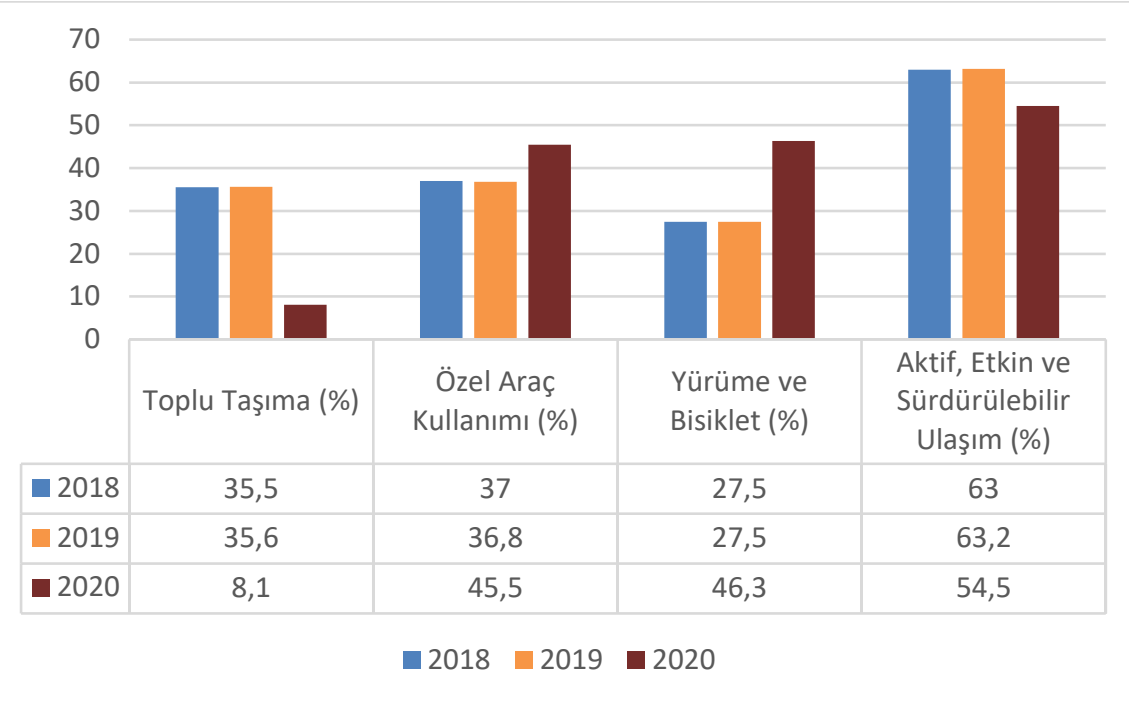

Şekil 1. Londra için 2018 ve 2019 yılı kent içi ulaşımda türel dağılım ortalaması ve 2020 yılı ilk iki çeyrek türel dağılım ortalaması (London Assembly, 2020).

Tüm dünyanın çeşitli kentlerinde ortaya konulan söz konusu genel verilere ek olarak, Türkiye için İstanbul özelinde yapılan araştırma ve bulgular ışığında ise, bu makale kapsamında 2019-2020 ve 2021 İstanbul ulaşım ve hareketlilik verileri kullanılarak pandeminin İstanbul ulaşımına nasıl etki ettiği araştırılmıştır.

TÜİK'in 2020 verilerine göre İstanbul yaklaşık 15,5 milyonluk bir nüfusa sahiptir (TÜIK, 2020). Nüfusun ve dolayısıyla hareketliliğin bu denli fazla olduğu bir kentin Türkiye'de salgının merkez üssü olması kaçınılmazdır. Ancak alınan sıkı önlemler ve kentsel hareketliliklerin mümkün olduğunca en aza indirilmesi ile Sağlık Bakanlığı verilerine göre 31 Temmuz-6 Ağustos 2021 haftası içinde Türkiye'de tespit edilen yaklaşık 166.000 vaka arasından İstanbul'un vaka oranı 100 binde 182,21 olarak açılanmıştır (TC. Sağlık Bakanlığı, 2021). Bu durum alınan önlemlerin virüsün yayılımının yavaşlatılması bakımından ne kadar önemli olduğunu göstermektedir. Nitekim nüfusu daha az olan kentlerde daha yüksek vaka oranları ile karşılaşılması 
İstanbul'un nispeten başarılı bir grafik çizdiğini göstermektedir (TC. Sağlık Bakanlığı, 2021).

İkinci olarak, Türkiye'de ulaşım alanında alınan önlemler tartışması kapsamında Dünya Sağlik Örgütü (DSÖ)'nün 11 Mart 2020 tarihinde yayınladığı 51. Haftalık raporda vurgulandığı üzere COVID-19 hastalığının yayılmasındaki en önemli etkenin yakın temas olduğu bilinmektedir (DSÖ, 2020). Bu değerlendirmenin dünya ve Türkiye'deki yansımaları ise kentsel hareketliliklerin mümkün olduğunca azaltılmasına yönelik alınan önlemler olmuştur. Salgının hızını yavaşlatmak adına birçok ülkede yüz yüze eğitime ara verilmesi, esnek ve evden çalışma olanaklarının kullanılması, şehir içi ve şehirlerarası ulaşımda çeşitli kısıtlamalar uygulanması gibi önlemler almıştır (Erbaş, 2020). 11 Mart 2020 tarihinde Türkiye'de ilk Covid-19 Vakasının görülmesinden sonra ülkede tüm okullar kapatılarak eğitime ara verilmiştir. 16 Mart tarihinde tüm okul ve üniversitelerde yüz yüze eğitime ara verilmesi ev-okul yolculuklarını durdurmuş ve hareketliliğin azalmasını sağlamıştır. Kapanmanın ilk olarak geçici olduğu açıklansa da durumun ciddiyetinin ve vaka sayılarının artması göz önünde bulundurularak tüm eğitim faaliyetleri uzaktan eğitimle yürütülmeye başlanmıştır (Eken, Tosun, ve Eken, 2020). Söz konusu dönemler içerisinde eğitime kademeli olarak başlanacağ söylenmiş olsa da tam anlamıyla yüz yüze eğitime başlanamamıştır. KısacaS1 2019-2020 ve 2021 ulaşım verileri kullanılarak yapılan bu çalışma döneminde 2020 ve 2021 yılları için kullanılan verilerde uzaktan eğitim yapılmakta olduğu için günlük yolculuklarda ev-okul yolculukları bulunmamaktadır. Ayrıca, 21 Mart 2020 tarihinde 65 yaş üstü ve kronik hastalığa sahip kişilerin sokağa çıkması yasaklanmıştır (Erbaş, 2020). Bu durum özellikle İstanbul'da toplu taşımayı ücretsiz kullanan 65 yaş üstü vatandaşların ulaşım sisteminden çıkmasına neden olmuştur. 23 Mart 2020 tarihinde ise tüm toplu taşıma araçlarında \%50 kapasite ile yolcu taşıma kararı alınmıştır. Toplu taşıma araçlarında ayakta alınabilecek yolcu sayısı sınırlandırılmıştır (Amerika'nun Sesi, 2020). Ayrıca ülke içinde yolculuk hareketliliğini sınırlamak için 3 Nisan 2020 tarihinde 30 Büyükşehir ve Zonguldak İl sınırlarından kara, hava ve deniz yoluyla yapılacak tüm giriş çıkışlar 15 gün süreyle durdurulmuştur. 18 Nisan'da bu yasak 15 gün daha uzatılmıştır. Yine aynı dönemde Türk Hava Yolları'nın iç hat seferleri durdurulmuştur. Birçok ülke ile karşllıklı olarak uçuşlar durdurulmuştur. Görüldüğüu üzere Türkiye'de salgın kapsamında alınan ilk önlemler tüm dünyada olduğu gibi insan hareketliliğini en aza indirmeyi amaçlamıştır (Erbaş, 2020). 
Üçüncü olarak, Türkiye'nin en kalabalık metropoliten alanı olan İstanbul'da kentsel hareketliliğin azaltılmasına yönelik alınan önlemlerin toplu taşıma kullanımı oranlarına yansıması beklenildiği gibi olmuştur. 2019 ve 2020 Temmuz ayı metro ve hafif raylı sistemlere yönelik günlük kullanımlar karşılaştıııldığında, önceki dönemlere kıyasla neredeyse yarı yarıya azalmanın söz konusu olduğu görülmektedir. Söz konusu azalma ise metrobüs kullanımında \% 40, Marmaray'da \% 34 olmuştur (IBB, 2019; 2020; 2021). Benzer şekilde otobüs kullanıcılarının sayısı da yarı yarıya düşmüştür. Kısaca insanların evden çalışma ve uzaktan eğitimin de etkisiyle kentsel ulaşım ihtiyacı azalmıştır. Aynı zamanda insanların toplu taşıma kullanımına bakışı da hastalıkla beraber değişim göstermiştir (Tosman, 2021).

Türkiye'de ilk vakanın görüldüğü Mart ayı itibari ile alınan sağlık önlemleri kapsamında toplu taşıma kullanımında bariz bir azalma olmuştur. Örneğin 1 Haziran 2020'de normalleşme dönemi olmasına rağmen 2019 Temmuz ayında ortalama metro yolculuğu sayısı hafta içi günlük 1 milyon 290 bin civarındayken, bu sayının 2020 yılında 678 bin olduğu görülmektedir (IBB, 2019; 2020). 2021 yılında ise yolculuk sayılarında bir artış olmakla beraber pandemi öncesi dönemdeki yolculuk sayılarına yaklaşılamamıştır. Örneğin 2020 Mayıs ayı hafta içi metro ile yapılan yolculuk sayısı ortalama 206 bin iken bu sayı 2021 Mayıs ayında 530 bine çımıştır (IBBB, 2020; 2021). 2021 yılı Mayıs ayının ilk yarısında sağlık tedbirlerinin ve tam kapanma önlemlerinin işletildiği göz önünde bulundurulduğunda söz konusu metro kullanımı oranlarının arttığı söylenilebilir. Metro kullanımı herhangi bir tedbir uygulamasının olmadığı Mart ayında 939 bin civarında seyretmiştir (İBB, 2019; 2020; 2021). İstanbul'da özel araç sahiplilik oranı 2019'dan 2021 yılına kadar artış göstermiştir. 2019 yılında binde 192 olan otomobil sahiplilik oranı 2021 yılında binde 201'e çıkmıştır. Bu noktada, özel araç sahipliliğindeki artış trafik yoğunluğuna da yansımıştır. Pandemi sürecinin etkisiyle İstanbul' da toplu taşıma kullanımlarında bariz düşüşlerin söz konusu olduğu ve bu düşüşlerin ağırlıkla özel araç kullanımlarıyla ikame edildiği açıkça ifade edilebilir (Tosman,2021). Ayrıca, yapılan gözlemler ışı̆̆ında, pandeminin ilk zamanlarında İstanbul'da ortalama trafik indeksinin pandemi başlamadan önceki değerlerinin \% 20-\%30'lar civarında olduğu görülürken, 2021 yılının başında ise bu indeksin \% 42 ile \% 43 arasındaki seviyelere çıktığı gözlemlenmiştir, yolculukların en yoğun olduğu pik saatlerde ise söz konusu oranların İstanbul için \% 60'ın üzerine çıtı̆̆ görülmektedir (İBB Açık Veri Portalı,2021). 
Benzer şekilde Apple Hareketlilik Trend Raporlarınca 13 Ocak 2020 tarihinden 10 Ağustos 2021 tarihine kadar yayınlanmış olan verilerin analizine göre İstanbul'da günlük hareketlilikte yürüme aktivitesi \% 96 artarken, ulaşımda özel araç kullanımı \% 79 artmıştır (Apple, 2021).

Pandemi öncesi 2019 ve pandemi sırasındaki 2020 ve 2021 yıllarının Mayıs, Haziran ve Temmuz ayına ait İstanbul'da toplu taşımanın türel dağılımı aşağıdaki grafikte (Şekil 2) gösterilmektedir (IBBB, 2019; 2020; 2021).

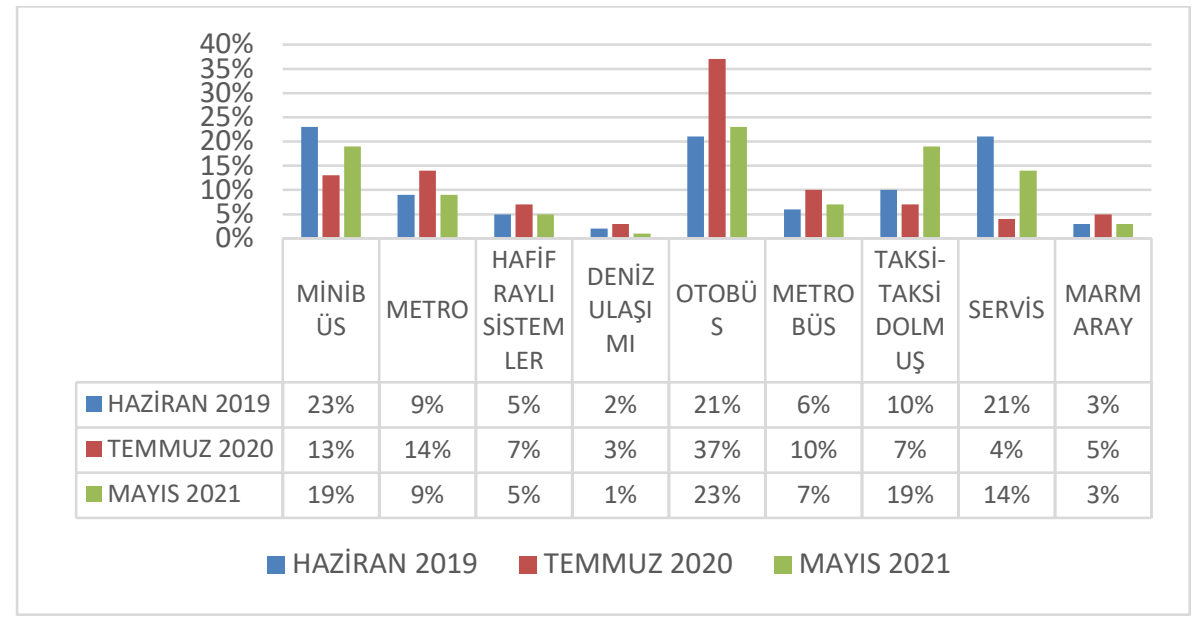

Şekil 2. İstanbul'da toplu taşımanın türel dağllımı (IBB, 2019; 2020; 2021).

Toplu taşıma kullanımındaki dalgalanmalar dikkat çekicidir. Bu dalgalanmalarda kapanmaların, sokağa çıkma yasaklarının ve evden çalı̧̧ma olanaklarının etkili olduğu ifade edilebilir. Temmuz 2020 tarihinde görülen ani toplu taşım kullanımı artışı 1 Haziran 2020 itibariyle başlayan normalleşme süreci ile ilişkilendirilebilir. Tekrar 2021 yılı mayıs ayında gerçekleşen tam kapanmanın etkisiyle toplu taşıma kullanımında dalgalanmalar gözlemlenmiştir (IBBB, 2019; 2020; 2021).

COVID-19 pandemisi ile beraber İstanbul içerisinde gerçekleştirilen ulaşım hareketliliklerinde en dikkat çekici değişikliğin özel araç kullanımlarında olduğu söylenebilir. İstanbul Büyükşehir Belediyesi toplu taşıma verilerine göre pandeminin başlangıcından önce yani 2019 Mart ayı ilk haftasında insanların \%75'i günlük aktivitelerinde ev dışında iken, Mart ayı sonunda bu oran \%16'ya düşmüştür (İBB, 2019). Buna rağmen özel araç kullanımı aynı haftalarda \%15'ten \%54'e çıkmıştır. Bu durum, insanların mümkün olduğunca az temas ile hastalıktan korunma çabasının bir sonucu olarak değerlendirilebilir. Mart ayının ilk haftasında ise toplu taşıma kullanımı 
oranı \% 42 iken, Mart ayı sonunda bu oran \% 20'ye gerilemiştir. (Tosman, 2021).

Söz konusu genel bilgilendirmeleri takiben çalışmanın bir sonraki bölümü olan yöntem tartışmaları içerisinde, söz konusu istatistiksel analizlere altlık oluşturan Haziran 2019, Temmuz 2020 ve Mayıs 2021 yolculuk verileri ile yöntemsel çerçeve anlatılmıştır. Çalışmanın Bulgular ve Tartışma bölümlerinde ise model sonuçlarının açıklanması akabinde İstanbul özelindeki toplu taşıma kullanımında diğer ulaşım türlerine kıyasla olan bariz değişimler üzerinden toplu taşıma türüne olan pandemi sonrası yeni bakış açısı tartışılmıştır. Çalışmanın son bölümünde ise günümüz koşullarındaki uygulamaların (tekrar kapanmalar vs gibi) önümüzdeki süreçlerdeki olası etkileri ortaya konulmuştur.

\section{Veri ve Yöntem}

Makalenin bu bölümünde, İstanbul içerisinde pandemi sürecinin de etkisiyle toplu taşıma türleri bazındaki değişimlerin ortaya konulmasına yönelik olarak kullanılan veri ve değişkenler ile yöntemsel çerçeve detaylı bir şekilde açıklanmıştır.

\section{Veri}

Pandemi sürecinin etkisiyle İstanbul'daki toplu taşıma kullanımlarına yönelik değişim eğilimlerinin deneysel olarak değerlendirilmesi amacıyla ortaya konulan verilere yönelik olarak, İstanbul Büyükşehir Belediyesi'nce yayınlanan Haziran 2019, Temmuz 2020 ve Mayıs 2021 yolculuk verileri üzerinden iki temel değişken başlığı tanımlanmıştır. Bunlar, belirtilen tarihler içerisinde otobüs, metrobüs, metro, hafif raylı sistemler, Marmaray ve deniz ulaşımı olmak üzere altı farklı ulaşım türü aracılığıyla gerçekleştirilen günlük yolculuk sıklıkları ve T.C. Sağlık Bakanlığı'nca yayınlanan günlük vaka sayıları (100 binde) şeklindedir. Bu noktada, belirtilen her bir ulaşım türüne yönelik gerçekleştirilen günlük yolculuk sayıları verileri, her bir ulaşım türü için beş farklı sınıf aralığı üzerinden tanımlanmış olup, günlük vaka sayıları (100 binde) ise, birer sürekli değişken olarak tanımlanmıştır. Bir diğer ifadeyle, belirtilen ulaşım türleri bazında sergilenen günlük yolculuk sayıları en küçükten en büyüğe sıralanmaları suretiyle beş ayrı sınıf aralığı üzerinden birer kategorik veri olarak tanımlanmışken, günlük vaka sayısı (100 binde) değişkeni ise normal dağılım gösteren sürekli bir veri seti olarak tanımlanmıştır (Tablo 1). 
Tablo 1. Değişkenler ve veri seti.

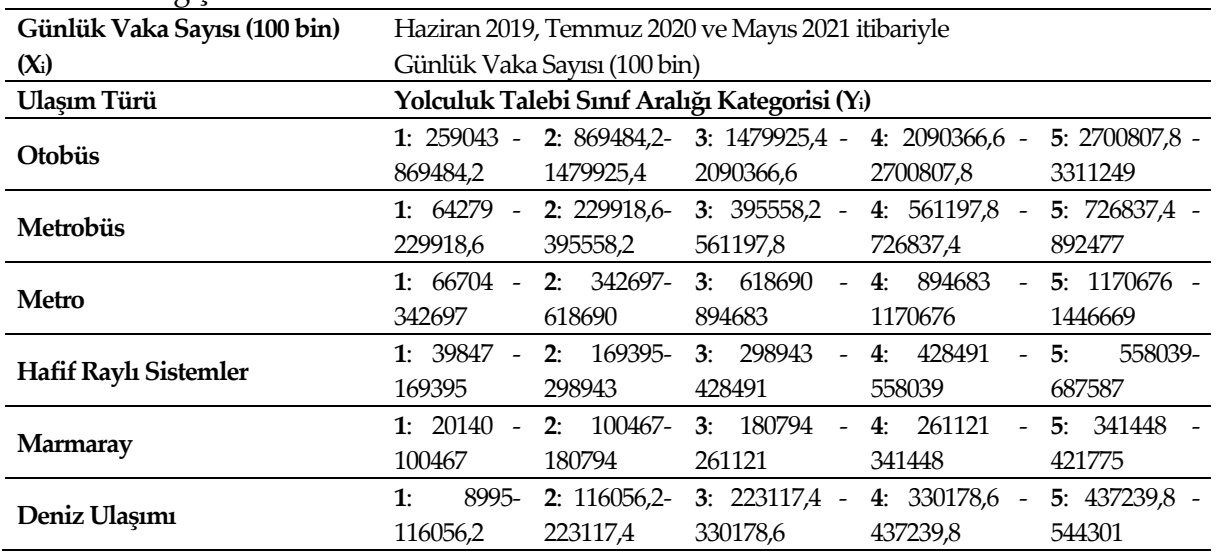

Tablo 1'den de takip edilebileceği üzere, örneğin otobüs türü için gözlenen günlük yolculuk sayısı 259.043 ile 869.484 arasında ise, ilgili ÇTLB modelinde otobüs türü için ortaya konulan bağımlı değişken, "1" değerini alan bir kategorik değişken olarak tanımlanmıştır. Benzer şekilde otobüs türü için gözlenen günlük yolculuk talebi 2.700.807 ile 3.311.249 arasında ise, söz konusu modeldeki bağımlı değişken, " 5 " değerini alan bir kategorik değişken olarak tanımlanmiştır.

Böylelikle, İstanbul Büyükşehir Belediyesi'nce Haziran 2019, Temmuz 2020 ve Mayıs 2021 tarihleri boyunca her bir yolculuk türü özelinde ayr1 ayrı yayınlanan günlük yolculuk sayısı verisi, Tablo 1'de belirtilen talep aralıkları bazında birer sıralı kategorik veri olarak ÇTLB modeli içerisinde tanımlanmıştır. ÇTLB modeli içerisinde tanımlanan her bir bağımlı kategorik değişkene yönelik açıklayıcı bağımsız değişken olarak ise, Sağlık Bakanlığı'nca ilgili tarihler boyunca yayınlanan günlük 100 bin kişide görülen COVID vaka sayısı değişkeni tanımlanmış olup, her bir yolculuk türü özelinde söz konusu vaka miktarlarının günlük yolculuk taleplerine olan etkisi modellenmiştir.

\section{Yöntem}

Kategorik veri tipleri odaklı yöntem ve modeller, sosyal bilimlere yönelik uygulamalı araştırmalarda son zamanlarda sıkça başvurulan bir yöntemsel yaklaşıma işaret etmektedir. Bu bağlamda, özellikle kategorik veri üzerinden yürütülen deneysel çalışmalarda kullanılan doğrusal olmayan bağlanım modelleri arasında Çok Terimli Logit Bağlanım (ÇTLB) modellerine ilgi gittikçe artmaktadır. 
Model yapısı itibariyle iki terimli lojistik bağlanım modeli yapısının geliştirilmiş bir türü olan ÇTLB, en az üç kategorik değişkenin söz konusu olduğu araştırmalarda sıkça başvurulan bir yöntemdir (Cameron ve Trivedi, 2005; El-Habil, 2012). Bu noktada söz konusu ÇTLB modeli, en az üç kategorik değişkenin birer bağımlı değişken olarak tanımlanabildiği ve bu bağımlı değişkenlere yönelik açıklayıcı değişkenlerin ise normal dağılım gösteren sürekli ya da kategorik veri yapılarını içerebildiği bir model yapısına işaret etmektedir (Cameron ve Trivedi, 2005; El-Habil, 2012). Ek olarak ÇTLB modeli, bağımlı değişken olarak tanımlanabilecek olan en az üç kategorik değişkenin her birine yönelik logaritmik olasılık oranı tahminlerinin eş zamanlı olarak yapılmasına olanak tanımaktadır (Cameron ve Trivedi, 2005; El-Habil, 2012).

Bu makale kapsamında ortaya konulan araştırma sorusu kapsamında ise, İstanbul içinde aktif olarak kullanılan toplu taşıma seçenekleri olan otobüs, metrobüs, metro, hafif raylı sistemler, Marmaray ve deniz ulaşımı türlerinin her birine yönelik olan günlük yolculuk sayılarının işaret ettiği yolculuk talebi kategorilerinin, ilgili tarihlerdeki günlük ortalama COVID vaka sayısı (100 bin) değişkeninden ne derece etkilendikleri araştırılmıştır. Bir diğer ifadeyle, ÇTLB modeli aracılı̆̆yyla toplu taşıma kategorisi içerisindeki hangi ulaşım türlerinin COVID salgınından görece daha fazla etkilendiği, ilgili tekil etki katsayılarının tahmin edilmesi suretiyle ortaya konulmuştur. Böylelikle söz konusu toplu taşıma türleri bazındaki yolculuk taleplerine yönelik tanımlayıc istatistiksel verilerin sergilenmesinin ötesinde, belirli bir güven aralığ1 içerisinde genelleştirilebilir istatistiksel çıkarımlar üretilmiştir. Bu noktadan hareketle kurulan ÇTLB modeli yapısı içerisinde otobüs, metrobüs, metro, hafif raylı sistemler, Marmaray ve deniz ulaşımı türlerinin her biri bazındaki yolculuk talebi kategorisi birer kategorik bağımlı değişken olarak tanımlanmıştır. Öte yandan ilgili tarihlere yönelik günlük ortalama COVID vaka sayısı (100 bin) ise, her bir ulaşım türü için kurulan modellerde ayrı birer açıklayıcı değişken olarak tanımlanmıştır (Eşitlik 1):

$$
\begin{aligned}
& \operatorname{Logit}\left[P\left(Y_{i}=1\right)\right]=\alpha_{i}+\beta_{i} X_{i}+e_{i} \\
& i=1,2,3,4,5,6 .
\end{aligned}
$$

Burada ${ }^{i}$ her bir ulaşım türüne yönelik tanımlanan beş yolculuk talep kategorisinden her birini, $Y_{i}$ ilgili ulaşım türü için sergilenen yolculuk talebi kategorileri içerisinden ${ }^{i}$ kategorisinin işaret ettiği sınıf aralıklarının ortanca 
değerini ve $X_{i}$ ilgili tarihlere yönelik günlük ortalama COVID vaka sayısını (100 bin) temsil etmektedir (Tablo 1). Ek olarak, $\beta_{i}$ günlük ortalama COVID vaka sayısındaki (100 bin) bir birimlik artışın, ilgili ulaşım türüne yönelik yolculuk taleplerinin işaret ettiği $i$ talep kategorisine yönelik logaritmik olasılık oranında ne kadarlık bir değişimin oluşabileceğinin ölçümünü ve $e_{i}$ söz konusu ulaşım türüne yönelik i yolculuk kategorisi için oluşturulan modeldeki hatayı temsil etmektedir. Son olarak $\operatorname{Logit}\left[P\left(Y_{i}=1\right)\right]$ ise ilgili ulaşım türü için belirlenen ${ }^{i}$ talep kategorisine yönelik logaritmik olasılık oranı $(\log$ odds) tahminine işaret etmektedir. İlgili terim içerisindeki $Y_{i}=1_{\text {ifadesi ise, gözlenen yolculuk talebinin, ilgili ulaşım türü için belirle- }}$ nen $i$ talep kategorisine ait olma durumunu temsil etmektedir (Eşitlik 2):

$$
\Pi\left(Y_{i}=1\right)=\frac{\exp \left(\alpha_{i}+\beta_{i} X_{i}+e_{i}\right)}{\left.1+\sum_{i=1}^{i=5} \alpha_{i}+\beta_{i} X_{i}+e_{i}\right)}
$$

Burada $\Pi\left(Y_{i}=1\right)$ ifadesi, ilgili ulaşım türüne yönelik yolculuk talebinin, yine ilgili ulaşım türü için belirlenen $i$ talep kategorisine işaret etmesi olasılığına işaret etmektedir. Ayrıca $\exp \left(\alpha_{i}+\beta_{i} X_{i}+e_{i}\right)$ ise günlük ortalama COVID vaka sayısındaki (100 bin) bir birimlik artışın, ilgili ulaşım türüne yönelik yolculuk taleplerinin işaret ettiği $i$ talep kategorisine yönelik logaritmik olasılık oranına olan çarpımsal etkisine işaret etmektedir.

Ek olarak, her bir ulaşım türüne yönelik ortaya konulan yolculuk talebi kategorilerinden bir tanesi, ÇTLB modeli yapısı gereği temel düzey (base level) olarak seçilmiş ve geri kalan yolculuk talebi kategorilerine yönelik logaritmik olasılık oranları ise, ilgili ulaşım türü için belirlenmiş olan söz konusu temel düzey kategorisi üzerinden hesaplanmıştır. Dolayısıyla söz konusu ÇTLB modeli yapısı, aşağıda gösterilen formu (Eşitlik 3) almaktadır:

$$
\log \left(\frac{\Pi_{\mathrm{i}}\left(\mathrm{Y}_{\mathrm{i}}=1\right)}{\Pi_{\mathrm{k}}\left(\mathrm{Y}_{\mathrm{i}}=1\right)}\right)=\alpha_{i}+\beta_{i} X_{i}+e_{i}
$$

Burada $i=1,2,3,4,5$ daha önce de belirtildiği üzere her bir ulaşım türüne yönelik tanımlanan beş kategoriden her birini, $Y_{i}$ ise ilgili ulaşım türü için 
sergilenen yolculuk talebi kategorileri içerisinden ${ }^{i}$ kategorisinin işaret ettiği sınıf aralıklarının ortanca değerini ve $X_{i}$ ilgili tarihlere yönelik günlük ortalama COVID vaka sayısını (100 bin) temsil etmektedir. Bu noktadan hareketle tahmin edilecek olan söz konusu olasılık değerlerinin toplamının 1' e eşit olmasının sağlanması adına yukarıda verilen Eşitlik 3, aşağıda verilen eşitlik yapısına (Eşitlik 4) indirgenebilmektedir:

$$
\log \Pi i(Y i=1)=\frac{\exp \left(\alpha_{\mathrm{i}}+\beta_{\mathrm{i}} \mathrm{X}_{\mathrm{i}}+e_{i}\right)}{\sum_{j=1}^{k-1} \exp \left(\alpha_{\mathrm{i}}+\beta_{\mathrm{i}} \mathrm{X}_{\mathrm{i}}+e_{i}\right)}
$$

Ek olarak, ÇTLB modeli çerçevesi aracilığıyla ortaya konulan olasılık tahminleri, her bir ulaşım türü için belirlenen yolculuk talebi kategorilerinden birinin temel düzey olarak seçilmesi akabinde geriye kalan her bir kategorinin seçilen temel düzey kategorisi ile karşılaştırılması suretiyle hesaplanmaktadır. Böylelikle, söz konusu ÇTLB modeli aşağıdaki forma dönüşmektedir (Eşitlik 5):

$$
\underset{i \neq j}{\log \left(\frac{\Pi_{\mathrm{i}}\left(\mathrm{Y}_{\mathrm{i}}=1\right)}{\prod_{\mathrm{j}}\left(\mathrm{Y}_{\mathrm{j}}=1\right)}\right)}=\alpha_{i}+\beta^{\prime}{ }_{i} X_{i}
$$

Ayrıca ÇTLB modeli aracılığıyla $\Pi\left(Y_{i}=1\right)$ ifadesi ile temsil edilen söz konusu ulaşım türüne yönelik yolculuk talebinin, yine ilgili ulaşım türü için belirlenen $i$ talep kategorisine işaret etmesi olasılıkları, her bir yolculuk kategorisi için aşağıdaki eşitlik (Eşitlik 6) üzerinden tahmin edilebilmektedir:

$$
\Pi\left(Y_{i}=1\right)=\frac{\exp \left(\alpha_{\mathrm{i}}+\beta_{\mathrm{i}} \mathrm{X}_{\mathrm{i}}\right)}{\sum_{i=1}^{i-1} \exp \left(\alpha_{(i-1)}+\beta_{(i-1)} \mathrm{X}_{(i-1)}\right)}
$$

Böylelikle tüm ulaşım türleri için her bir ulaşım türüne yönelik yolculuk talebinin, yine ilgili ulaşım türü için belirlenen $i$ talep kategorisine işaret etmesi olasılıklarının toplamı 1 'e eşit olmaktadır (Eşitlik 7): 


$$
\sum_{i=1}^{i=5} \Pi_{i}=1
$$

Son olarak, her bir ulaşım türüne yönelik yolculuk talebinin, yine ilgili ulaşım türü için belirlenen ${ }^{i}$ talep kategorisine işaret etmesine yönelik olastlık tahminlerinin ${ }^{\bar{\Pi}_{i}}$ ile temsil edilmesi ile aşağıdaki bağıntılar (Eşitlik 8) elde edilebilmektedir:

$$
\begin{aligned}
& \bar{\Pi}_{2}=\frac{\exp \left(Y_{2}\right)}{1+\exp \left(Y_{1}\right)+\exp \left(Y_{2}\right)+\exp \left(Y_{3}\right)+\exp \left(Y_{4}\right)+\exp \left(Y_{5}\right)} \\
& \bar{\Pi}_{3}=\frac{\exp \left(Y_{3}\right)}{1+\exp \left(Y_{1}\right)+\exp \left(Y_{2}\right)+\exp \left(Y_{3}\right)+\exp \left(Y_{4}\right)+\exp \left(Y_{5}\right)}, \\
& \bar{\Pi}_{4}=\frac{\exp \left(Y_{4}\right)}{1+\exp \left(Y_{1}\right)+\exp \left(Y_{2}\right)+\exp \left(Y_{3}\right)+\exp \left(Y_{4}\right)+\exp \left(Y_{5}\right)}, \\
& \bar{\Pi}_{5}=\frac{\exp \left(Y_{5}\right)}{1+\exp \left(Y_{1}\right)+\exp \left(Y_{2}\right)+\exp \left(Y_{3}\right)+\exp \left(Y_{4}\right)+\exp \left(Y_{5}\right)} \\
& \bar{\Pi}_{1}=\frac{1}{1+\exp \left(Y_{1}\right)+\exp \left(Y_{2}\right)+\exp \left(Y_{3}\right)+\exp \left(Y_{4}\right)+\exp \left(Y_{5}\right)}
\end{aligned}
$$

Buradaki varsayım, $\mathrm{i}=1$ kategorisinin temel düzey kategorisi olarak seçildiği ve diğer kategorilere yönelik olasıllk tahminlerinin ise bu temel düzey kategorisi ile karşılaştırılmaları suretiyle elde edilmiş olduğudur.

\section{Bulgular}

ÇTLB modeli sonuçlarına göre ilk olarak, günlük COVID vaka sayısı (100

\begin{tabular}{|c|c|c|c|c|c|c|}
\hline $\begin{array}{c}\text { Yolculuk } \\
\text { Türü Ba- } \\
\text { zinda Gün- } \\
\text { lük Yolcu- }\end{array}$ & 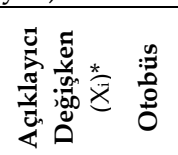 & 苋 & 离 & 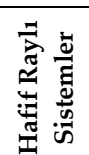 & 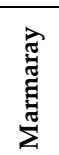 & 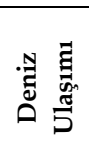 \\
\hline
\end{tabular}
binde) değişkeninin otobüs için 259 bin ile 869 bin arasında seyreden günlük yolculuk talepleri üzerindeki etki katsayısı 99 \% güven düzeyinde istatistiksel olarak anlamlı çkmıştır (Tablo 2).

Tablo 2. Yolculuk türleri için ÇTLB modeli bulguları $\left({ }^{*} \mathrm{X}_{\mathrm{i}}\right.$ : 100 bin kişide Günlük Ortalama Vaka Sayısı). 


\begin{tabular}{|c|c|c|c|c|c|c|c|c|c|c|c|c|c|}
\hline \multirow[t]{3}{*}{$\begin{array}{l}\text { luk Talep } \\
\text { Kategorisi } \\
\text { (Bağımlı } \\
\text { değişken:Yi) }\end{array}$} & & 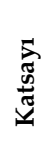 & $\mathrm{N}$ & 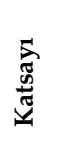 & $\mathrm{N}$ & 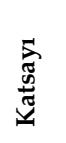 & $\mathrm{N}$ & 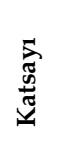 & $N$ & 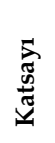 & $\mathrm{N}$ & 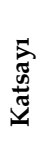 & $\mathrm{N}$ \\
\hline & $\left(X_{i}\right)$ & -0 & -3 & -0 & -4 & -0 & -3 & -0 & -4 & -0 & -4 & -0 & -1 \\
\hline & $\begin{array}{l}\text { Model } \\
\text { Sabiti }\end{array}$ & 0,1 & 0 & 1,3 & 2 & 0,3 & 1 & 1,6 & 3 & 2,2 & 3 & -3 & -4 \\
\hline \multirow[t]{2}{*}{1} & $\mathbf{X}_{\mathrm{i}}$ & 0,0 & 2 & 0,3 & 1 & 0,1 & 1 & 0,1 & 1 & 02 & 0 & -0 & -1 \\
\hline & $\begin{array}{l}\text { Model } \\
\text { Sabiti }\end{array}$ & -3 & -3 & -31 & -1 & -12 & -1 & -14 & -1 & -6 & -1 & -2 & -4 \\
\hline \multirow[t]{3}{*}{3} & \multicolumn{13}{|c|}{ TEMEL DÜZEY KATEGORİSİ } \\
\hline & $X_{i}$ & -2 & -0 & -0 & -3 & -0 & -3 & -0 & -3 & -0 & -4 & -2 & -0 \\
\hline & $\begin{array}{c}\text { Model } \\
\text { Sabiti }\end{array}$ & 0,6 & 1 & 2,3 & 4 & 0,9 & 1 & 2,5 & 3 & 2,5 & 4 & -3 & -3 \\
\hline \multirow{2}{*}{4} & $\mathbf{X}_{\mathrm{i}}$ & -2 & -0 & -2 & -0 & -2 & -0 & -2 & -0 & -2 & -0 & -2 & -0 \\
\hline & $\begin{array}{l}\text { Model } \\
\text { Sabiti }\end{array}$ & 2 & 3 & 3 & 4 & 2 & 4 & 3,7 & 5,0 & 3,8 & 5,0 & -2 & -3 \\
\hline \multicolumn{2}{|c|}{ Gözlem Sayısı } & \multicolumn{2}{|c|}{92} & \multicolumn{2}{|c|}{92} & \multicolumn{2}{|c|}{92} & \multicolumn{2}{|c|}{92} & \multicolumn{2}{|c|}{92} & \multicolumn{2}{|c|}{92} \\
\hline \multicolumn{2}{|c|}{$\begin{array}{l}\text { Olabilirlik Oranı } \\
\text { chi2(4) }\end{array}$} & \multicolumn{2}{|c|}{85,86} & \multicolumn{2}{|c|}{102,72} & \multicolumn{2}{|c|}{98,42} & \multicolumn{2}{|c|}{119,27} & \multicolumn{2}{|c|}{108,02} & \multicolumn{2}{|c|}{8,66} \\
\hline \multicolumn{2}{|l|}{ Olasılık > chi2 } & \multicolumn{2}{|c|}{0,0} & \multicolumn{2}{|c|}{0,0} & \multicolumn{2}{|c|}{0,0} & \multicolumn{2}{|c|}{0,0} & \multicolumn{2}{|c|}{0,0} & \multicolumn{2}{|c|}{0,1} \\
\hline \multicolumn{2}{|c|}{ Log Olabilirlik Oranı } & \multicolumn{2}{|c|}{$-83,76$} & \multicolumn{2}{|c|}{$-85,95$} & \multicolumn{2}{|c|}{$-84,6$} & \multicolumn{2}{|c|}{$-75,7$} & \multicolumn{2}{|c|}{$-75,32$} & \multicolumn{2}{|c|}{$-48,18$} \\
\hline \multicolumn{2}{|c|}{ Uyarlanmış $\mathbf{R}^{2}$} & & & 0, & & 0,3 & & 0, & & & & & \\
\hline
\end{tabular}

İkinci olarak, günlük COVID vaka sayısının metrobüs kullanımına yönelik talep düzeylerine olan etki katsayıları tahminleri, günlük metrobüs yolculuk taleplerinden üçünde 99 \% güven düzeyinde istatistiksel olarak anlamlı çımiştır. Söz konusu talep düzeyleri 64 bin ile 229 bin, 561 bin ile 726 bin ve 727 bin ile 893 bin arasında seyreden günlük yolculuk talepleri şeklindedir (Tablo 2).

Üçüncü olarak, günlük COVID vaka sayısı değişkeninin metro kullanımına yönelik talep düzeylerine olan etki katsayıları tahminleri, günlük metro yolculuk taleplerinin 67 bin ile 343 bin ve 894 bin ile 1 milyon 170 bin arasinda söz konusu olan günlük yolculuk talepleri için 99 \% güven düzeyinde istatistiksel olarak anlamlı çıkmıştır (Tablo 4).

Dördüncü olarak, günlük COVID vaka sayısı değişkeninin hafif raylı sistemlere yönelik talep düzeylerine olan etki katsayıları tahminleri, günlük hafif raylı sistem yolculuk taleplerinin 40 bin ile 169 bin ve 429 bin ile 558 bin arasinda söz konusu olan günlük yolculuk talepleri için istatistiksel olarak anlamlı çıkmıştır (Tablo 2).

Beşinci olarak, günlük COVID vaka sayısı değişkeninin Marmaray için 20 bin ile 101 bin ve 261 bin ile 342 bin arasında seyreden günlük yolculuk talep- 
leri üzerindeki etki katsayısı 99 \% güven düzeyinde istatistiksel olarak anlamlı çıkmıştır (Tablo 2).

Son olarak, günlük COVID vaka sayısı değişkeninin deniz ulaşımı türü için hiçbir günlük yolculuk talebi düzeyi üzerindeki etki katsayısı istatistiksel olarak en az 90 \% güven düzeyinde anlamlı çıkmamıştır (Tablo 2).

ÇTLB modeli sonuçlarını takiben ulaşım türleri bazında günlük vaka say1sının yolculuk talebi sınıf aralıkları üzerindeki tekil etki katsayısı tahminleri yapılmışır. Söz konusu tekil etki katsayısı tahminleri bulguları ise her bir ulaşım türü bazında beş gruba ayrılan günlük COVID vaka sayısı düzeyinin her biri için ayrı ayrı hesaplanmıştır.

Tekil etki katsayısı tahminleri bulguları içerisinde istatistiksel olarak anlamlı çıkan tahminlere göre ilk olarak, otobüs kullanımına yönelik günlük yolculuk taleplerinin beş gruba ayrılan günlük COVID vaka sayılarından ne düzeyde etkilendiği ortaya konulmuştur (Tablo 3). İlgili bulgulara göre, günlük otobüs yolculuk sayısının 259 bin 43 ile 869 bin 484 arasında seyrettiği günler içerisinde en az bir COVID vakasının görülmesi, otobüs türüne yönelik yolculuk taleplerinde \% 12,23'lük bir düşüşe yol açmıştır (Tablo 3).

Tablo 3. Günlük vaka sayısının (100 bin) farklı yolculuk türleri bazında sergilenen yolculuk talebi sınıf aralıkları üzerindeki tekil etki katsayısı tahminleri.

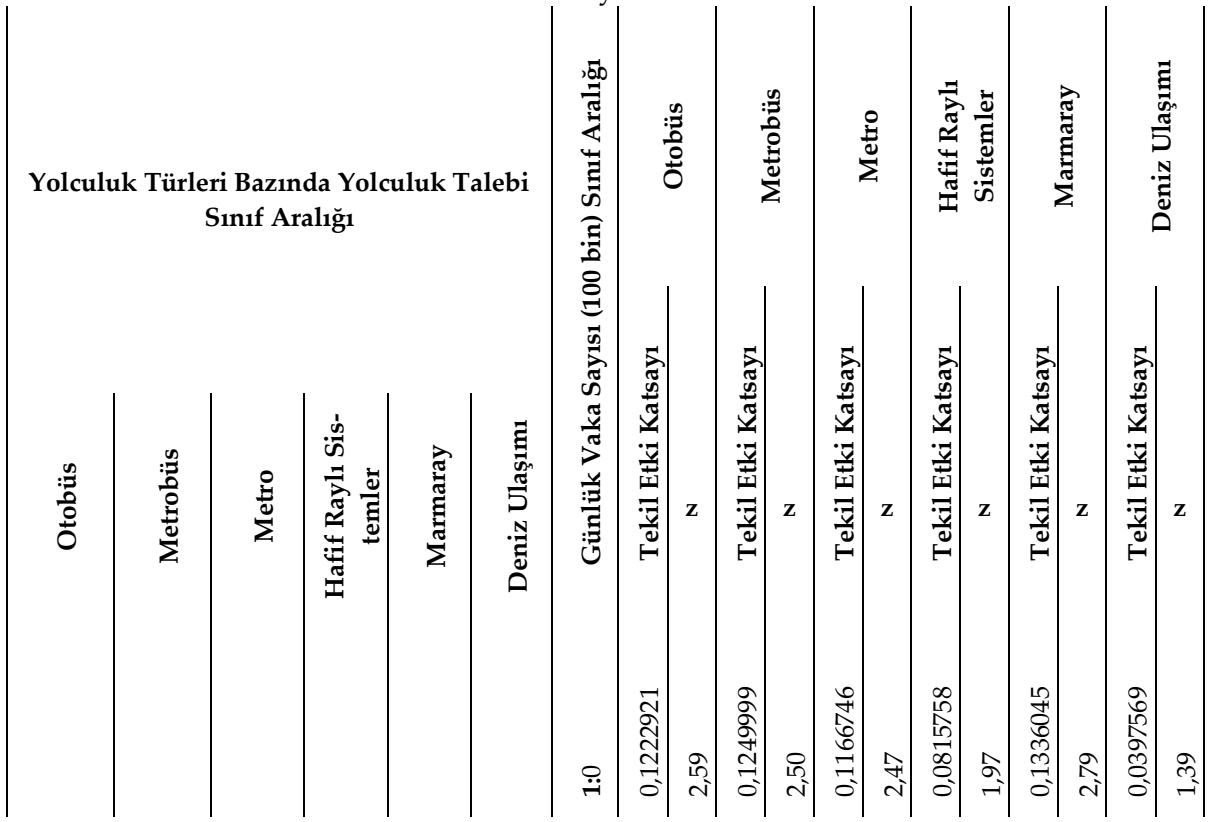




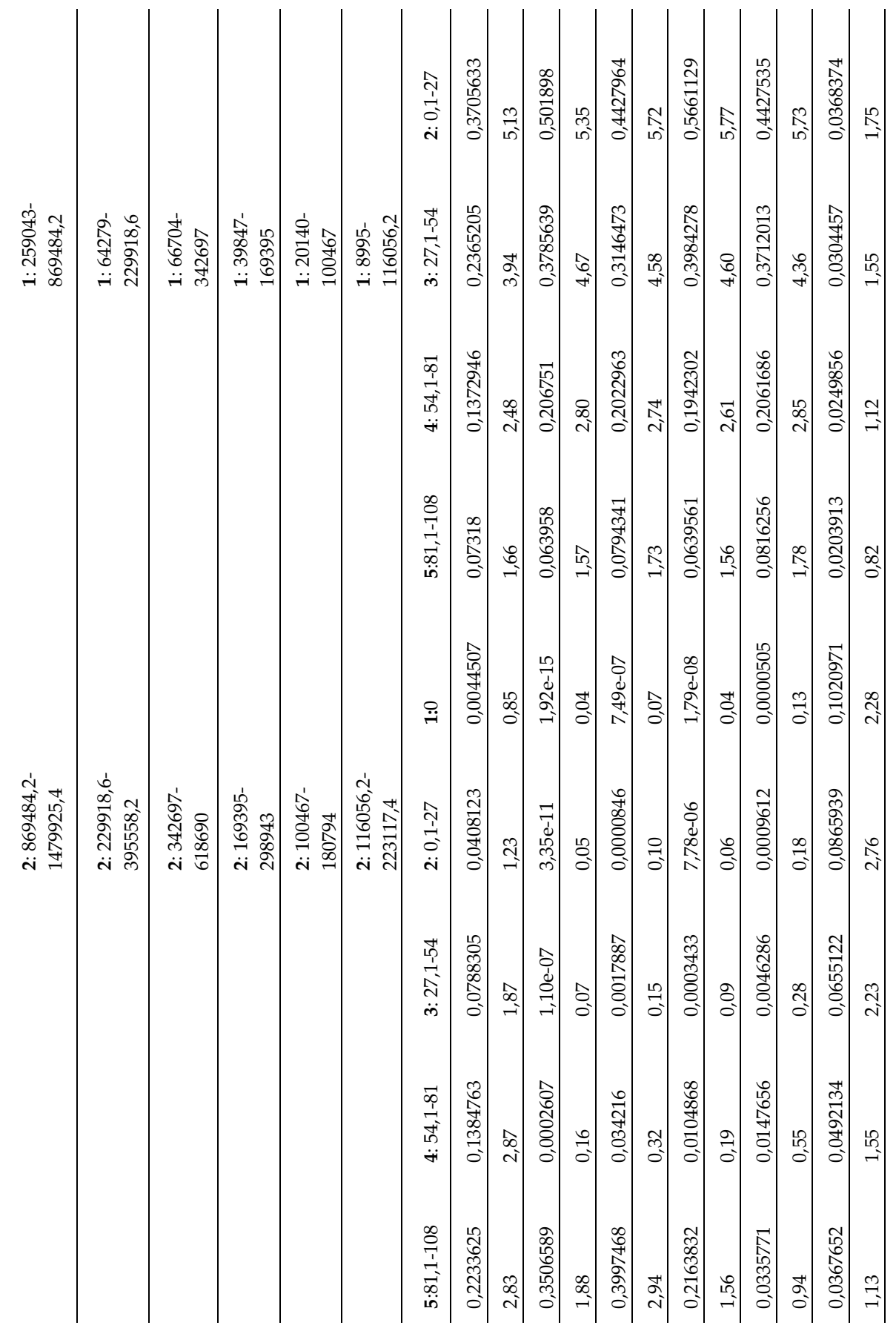




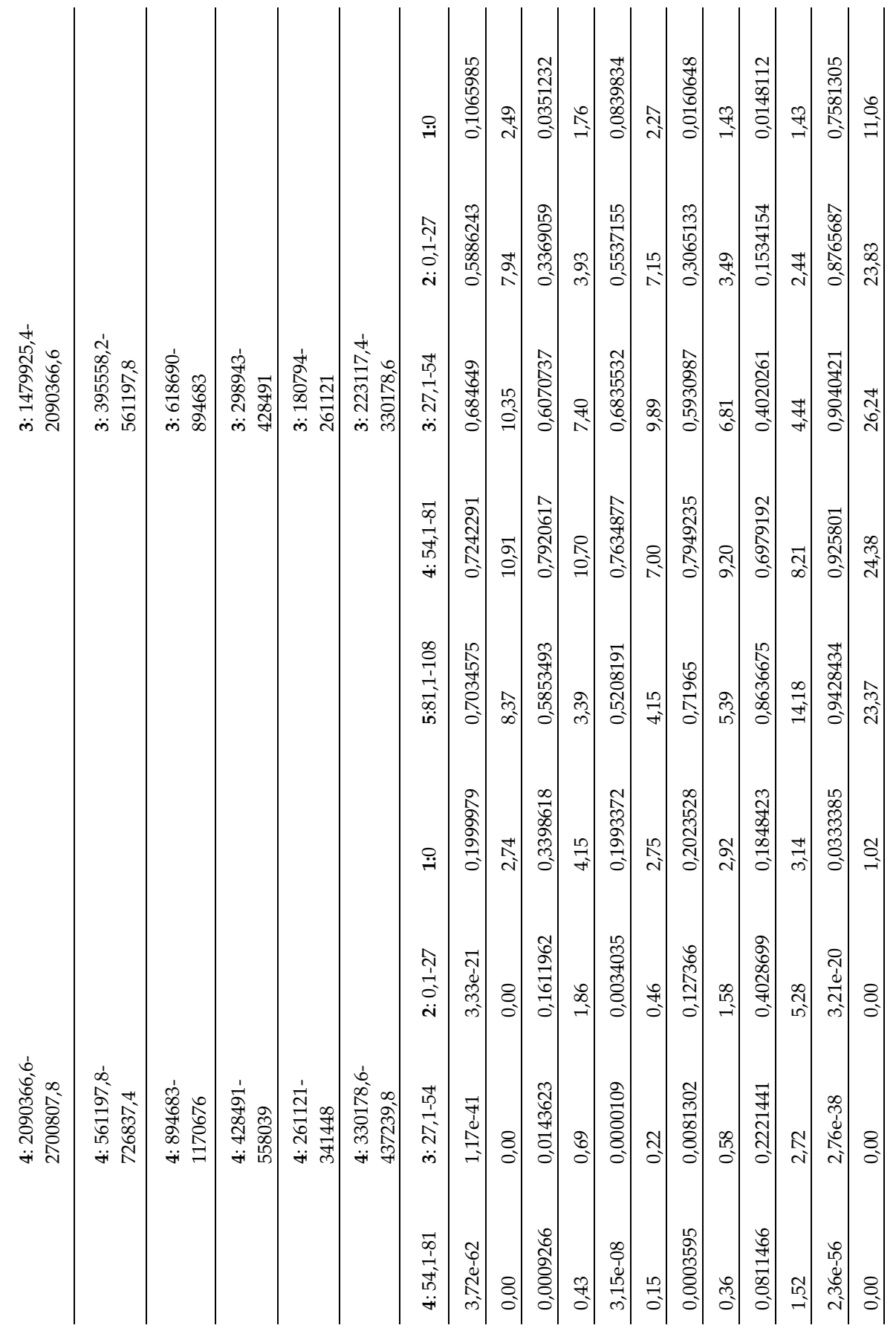




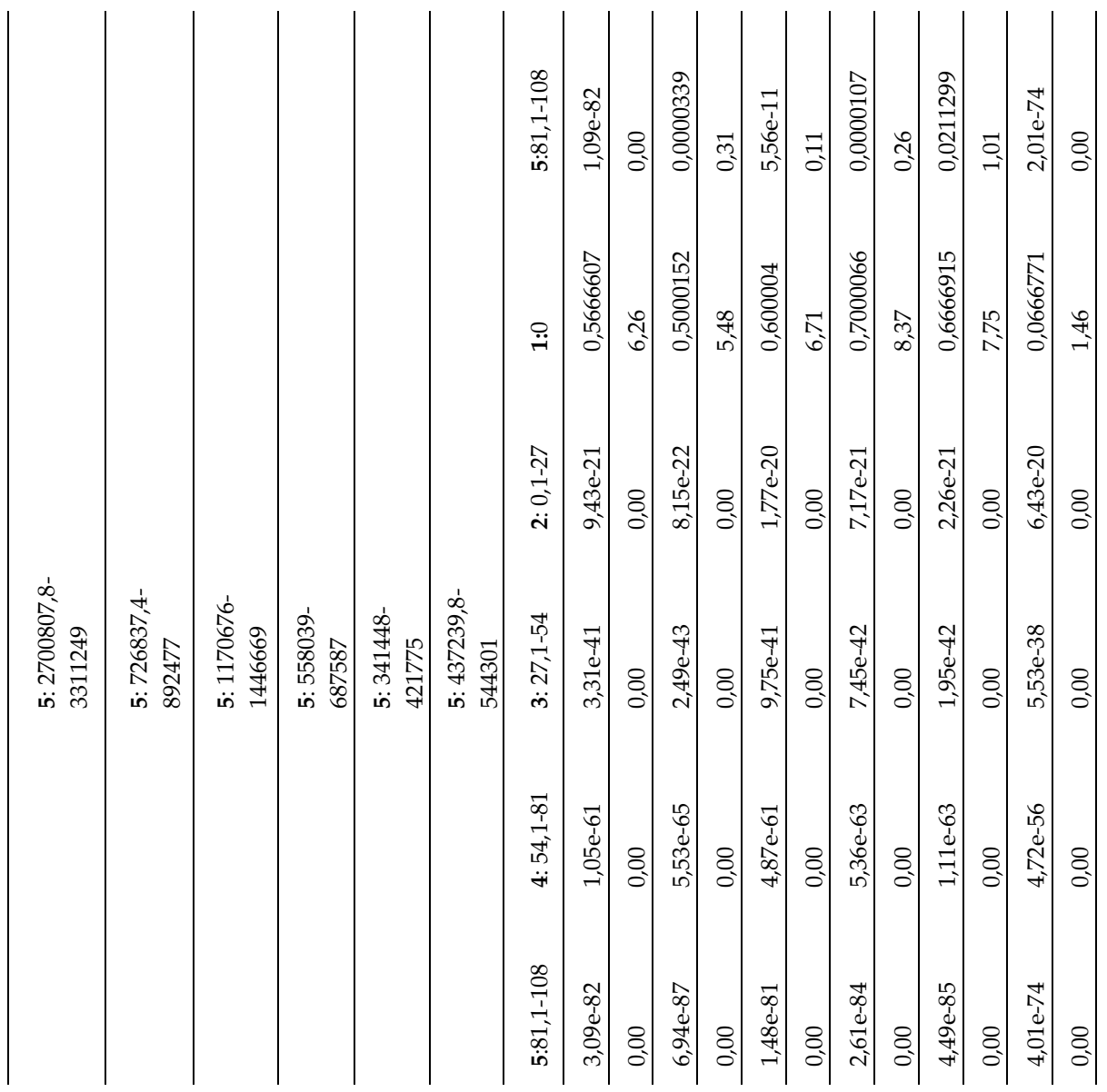

İkinci olarak, metrobüs kullanımına yönelik olan günlük 64 bin 279 ile 229 bin 919 arasında değişen metrobüs yolculukları için COVID vakasının görülmeye başlamasının, metrobüs kullanımlarına olan talepte \% 12,5'lik bir düşüşe neden olduğu tahmin edilmiştir (Tablo 3).

Günlük metrobüs yolculuklarını 561 bin 199 ile 726 bin 837 arasında seyrettiği talep düzeyi için ise COVID vakalarının görülmeye başlamasının, günlük metrobüs kullanım oranlarında $\% 33,99^{\prime}$ luk bir azalmaya sebep olduğu gözlenmiştir.

Metrobüs kullanımına yönelik son olarak günlük 726 bin 838 ile 892 bin 477 arasında değişen yolculuk talepleri için yapılan tahminler, COVID vakasının görülmeye başlanmasının günlük metrobüs yolculukları oranında \% 50'lik bir düşüşe yol açtığını göstermiştir. 
Üçüncü olarak, metro kullanımına yönelik günlük yolculuk sayılarının 66 bin 704 ile 342 bin 697 arasında değiştiği günlere yönelik yapılan tahminlere göre, COVID vakalarının gözlenmeye başlanmasının, metro kullanımlarında günlük \% 11,67'lik bir düşüşün gözlenmesine yol açtığı görülmüştür (Tablo 3).

Günlük yolculuk sayılarının 894 bin 684 ile 1 milyon 170 bin 676 arasında seyrettiği metro yolculukları için ise, COVID vakaların görülmeye başlaması durumunun, günlük metro kullanımı oranlarında \% 19,93'lük bir azalmaya sebep olduğu anlaşılmıştır.

Dördüncü olarak, günlük yolculuk sayısının 39 bin 847 ile 169 bin 395 arasında değiştiği aralık için bulunan tekil etki katsayı tahminleri, COVID vakalarının görülmeye başlamasının, hafif raylı sistem yolculuklarında günlük \% 8,16'lık bir düşüşe yol açtığını göstermiştir (Tablo 3).

Diğer taraftan, günlük yolculuk sayısının 428 bin 492 ile 558 bin 39 arasında seyrettiği aralık için bulunan tekil etki katsayı tahminlerine göre, pandemi vakalarının görülmeye başlaması durumunun, hafif raylı sistemlerin kullanımında günlük \% 20,24'lük bir azalmaya yol açtığı görülmüştür.

Beşinci olarak, Marmaray kullanımına yönelik olan günlük yolculuk sayılarının 20 bin 140 ile 100 bin 467 arasında değiştiği günlere yönelik yapılan tahminler, COVID vakalarının görülmeye başlanması durumunun, günlük Marmaray kullanım oranlarında \% 13,36'lık bir düşüşe yol açtı̆̆ına işaret etmiştir (Tablo 3).

Marmaray kullanımına yönelik günlük 261 bin 122 ile 341 bin 448 arasında seyrettiği yolculuk talebi düzeyi için yapılan tahminlere göre ise, COVID vakalarının gözlenmeye başlanması durumunun, Marmaray kullanımlarında günlük \% 18,48'lik bir azalmaya yol açtığı görülmüştür.

Altıncı olarak, deniz ulaşımı aracllı̆̆ıyla gerçekleştirilen günlük yolculuk sayısının 8 bin 995 ile 116 bin 56 arasında seyrettiği yolculuk düzeyi için yapılan tahminler arasında, sadece günlük COVID vaka sayısının 27 ve altında olması durumu için yapılan tahminler en az \% 90 güven aralığında istatistiksel olarak anlamlı çıkmıştır (Tablo 3).

Günlük yolculuk sayısının 223 bin 118 ile 330 bin 179 arasında seyrettiği talep düzeyi için istatistiksel olarak anlamlı çıkan tahminlere göre, COVID vakalarının gözlenmeye başlaması durumunun ise, deniz ulaşımı kullanımında günlük \% 87,65'lik bir azalmaya yol açtı̆̆ görülmüştür. 


\section{Tartışma}

ÇTLB modeli bulguları değerlendirmesinde, günlük vaka sayısından bağ1mız olarak COVID vakalarının görülmeye başlaması durumunun, farklı toplu taşıma türleri üzerindeki en büyük etkileri karşılaştırılmıştır.

İlk olarak, vakaların görülmeye başlaması durumunun otobüs türüne yönelik günlük kullanım sayısı üzerindeki en büyük tekil etkisi, İstanbul'da otobüsle gerçekleştirilen günlük 2 milyon 700 bin 809 ile 3 milyon 311 bin 249 arasında değişen yolculuk sayıları için hesaplanmıştır. Otobüs yolculuklarına yönelik belirtilen günlük talep aralığına işaret eden günler içerisinde vakaların görülmeye başlamasının günlük otobüs kullanımlarında $\% 56,67^{\prime}$ lik bir düşüşe yol açtığı tahmin edilmiştir. Ayrıca, COVID vakalarının görülmeye başlamasının günlük yolculuk taleplerinden ve vaka sayılarından bağımsız olarak otobüs kullanım oranlarını günlük ortalama \% 24,88 azalttı̆ı görülmektedir.

İkinci olarak, bulaş vakalarının görülmeye başlaması durumunun metrobüs türüne yönelik günlük kullanım sayısı üzerindeki en büyük tekil etkisi ise, İstanbul'da metrobüsle gerçekleştirilen günlük 726 bin 838 ile 892 bin 477 arasında değişen yolculuk sayıları için hesaplanmıştır. Belirtilen talep aralığı için günlük bulaş vakalarının görülmeye başlaması durumunun, günlük metrobüs kullanımlarında \% 50'lik bir düşüşe yol açtığı görülmektedir. İlave olarak, pandemi vakalarının görülmeye başlamasının metrobüs kullanım oranlarını günlük ortalama \% 25 azalttığı görülmektedir.

Üçüncü olarak, COVID vakalarının görülmeye başlaması durumunun metro türüne yönelik günlük kullanım sayısı üzerindeki en büyük tekil etkisi, İstanbul'da metro aracıllğıyla gerçekleştirilen günlük 1 milyon 170 bin 677 ile 1 milyon 446 bin 669 arasında seyreden yolculuk sayıları için hesaplanmıştır. Metro yolculuklarına yönelik ifade edilen söz konusu günlük talep aralığına işaret eden günler içerisinde vakaların görülmeye başlamasının günlük metro kullanımlarında \% 60'lık bir azalmaya yol açtığı görülmüştür. Ek olarak, COVID vakalarının görülmeye metro kullanım oranlarını günlük ortalama \% 25 azalttı̆g görülmektedir.

Dördüncü olarak, pandemi vakalarının görülmeye başlaması durumunun hafif raylı sistemlerin kullanımına yönelik günlük kullanım sayısı üzerindeki en büyük tekil etkisi ise, hafif raylı sistemler aracılığılla gerçekleştirilen günlük 558 bin 40 ile 687 bin 587 arasında değişen yolculuk sayıları için hesaplanmıştır. Söz konusu talep aralığı için günlük bulaş vakalarının görülmeye başlaması durumunun, hafif raylı sistemlere yönelik günlük yapı- 
lan yolculuklarda \% 70'lik bir azalmaya yol açtığı tahmin edilmiştir. Ayrıca, bulaş vakalarının görülmeye başlamasının hafif raylı sistemlere yönelik kullanım oranlarını günlük ortalama \% 32,80 azalttığı anlaşılmaktadır.

Beşinci olarak, bulaş vakalarının görülmeye başlaması durumunun Marmaray türüne yönelik günlük yolculuk talepleri üzerindeki en büyük tekil etkisi, İstanbul'da Marmaray aracılı̆̆ıyla gerçekleştirilen günlük 341 bin 449 ile 421 bin 775 arasında seyreden yolculuk sayıları için hesaplanmıştır. Belirtilen söz konusu talep aralığı için günlük bulaş vakalarının görülmeye başlaması durumunun, Marmaray'a yönelik günlük kullanımlarda \% 66,67'lik bir düşüşe yol açtığı görülmüştür. Ek olarak, COVID vakalarının görülmeye başlamasının Marmaray kullanım oranlarını günlük ortalama \% 32,84 azalttığı görülmektedir.

Son olarak, vakaların görülmeye başlaması durumunun deniz ulaşımı türü aracilığıyla gerçekleştirilen günlük kullanım sayısı üzerindeki en büyük tekil etkisi, İstanbul'da deniz ulaşımı ile yapılan günlük 223 bin 118 ile 330 bin 179 arasında değişen yolculuk sayıları için hesaplanmıştır. Belirtilen günlük talep aralığına işaret eden günler içerisinde vakaların görülmeye başlamasının günlük deniz ulaşımı kullanımında \% 75,81'lik bir düşüşe yol açtığı tahmin edilmiştir. Ayrıca, COVID vakalarının görülmeye başlamasının deniz ulaşımı kullanım oranlarını günlük ortalama \% 43 azalttığı görülmektedir.

Toparlamak gerekirse, İstanbul'da COVID vakalarının başlaması itibariyle kullanım oranlarında en çok düşüş görülen ulaşım türü \% 75,81 oranla deniz ulaşımı olmuştur. Deniz ulaşımını ise sırasıyla \% 70 ile hafif raylı sistemler, \% 66,67 ile Marmaray, \% 60 ile metro, \% 56,67 ile otobüs ve $\% 50$ ile metrobüs türleri takip etmektedir. İlave olarak, COVID vakalarının görülmeye başlamasının günlük yolculuk taleplerinden ve vaka sayılarından bağımsız olarak ulaşım türleri üzerindeki ortalama etkilerinden en büyüğü \% 43 ile yine deniz ulaşımı türü olmuştur. Söz konusu ortalama etki sıralamasında deniz ulaşımını \% 32,84 ile Marmaray, \% 32,80 ile hafif raylı sistemler, \% 25 ile metrobüs ve metro, \% 24,88 ile otobüs türleri takip etmektedir.

\section{Sonuç ve Değerlendirme}

2019 yılı sonu itibariyle COVID-19 virüsü, tüm dünyayı etkileyen ciddi bir salgına dönüşmüştür. Söz konusu salgının etkisiyle tüm dünya kentlerinde olduğu gibi İstanbul'da da ulaşım sektörü gözle görülür bir değişim geçirmiştir. Toplu taşıma kullanımı yerini daha güvenli olduğu düşünüldüğü 
için özel araç kullanımına bırakmıştır. Dolayısıyla, özellikle toplu taşıma kullanımlarına yönelik türel yolculuk dağılımları büyük ölçüde değişmiştir.

Bu çalışmada İstanbul'da yaşayan bireylerin ulaşım tercihlerinde görülen değişim, Çok Terimli Logit Bağlanım Modeli aracilı̆̆ıyla deneysel olarak ortaya konulmuştur. Çalışma kapsamında İstanbul'da toplu taşımada en çok kullanılan ulaşım türleri pandemi öncesi 2019 yıll, pandeminin en tavan yaptığı 2020 yılı ve pandeminin nispeten hafiflediği 2021 yılı İBB verileri ve İstanbul'da 100 bin kişide görülen günlük vaka sayıları kullanılarak modellenmiştir. Model sonuçlarına göre İstanbul'da pandemi etkisiyle otobüs, metrobüs, metro, hafif raylı sistemler, Marmaray ve deniz ulaşımı türlerinin kullanımı \%43 ile \%24 arasında değişen oranlarda azalış göstermiştir.

Söz konusu bulgulardan hareketle ilkin, ulaşım türlerine yönelik yolculuk talepleri arttıkça, bulaş riskinin söz konusu ulaşım türlerine yönelik kullanım oranlarında oluşturduğu kırılganlıkların arttı̆ı açıkça ifade edilebilir. İkinci olarak, Haziran 2019, Temmuz 2020 ve Mayıs 2021 tarihleri itibariyle pandemi sürecinden en çok etkilenen ulaşım türünün deniz ulaşımı olması dikkat çekicidir. Deniz ulaşımını ise sırasıyla Marmaray ve hafif raylı sistemler takip etmektedir. Öte yandan, COVID vakalarından en az etkilenen ulaşım türleri ise sırasıyla metrobüs ve otobüs türleri olmuştur. Bu noktada, COVID vakalarının yaygınlaşmasının kullanım oranlarını etkilemesi bakımından deniz ulaşımı ile yapılan yolculukların etkilenme oranının, metrobüs ve otobüs türleri ile yapılan yolculukların etkilenme oranlarına kıyasla yaklaşık iki kat fazla olması dikkat çekicidir. Söz konusu bulguların arka planında ilgili tarihler itibariyle gerek Türkiye'de gerekse de İstanbul'da hayata geçirilen kısıtlama uygulamalarının etkisi olduğu açıktır. Burada, özellikle 2020 yılı yaz ayları başı itibariyle işyeri kapanmalarına kademeli olarak ara verilmesi itibariyle ev bazlı iş yolculuklarının zaruri olarak devam etmesi, öte yandan rekreatif yolculukların ise minimumda tutulması eğilimi, özellikle metrobüs ve otobüs aracılı̆gıyla yapılan zaruri yolculuk sayılarının pandemi süreçlerinden diğer ulaşım türlerine kıyasla daha az etkilenmesi sonucunu doğurmuştur. Diğer taraftan deniz ulaşımının en az etkilenen ulaşım türü olması ise deniz ulaşımı aracılığıyla yapılan söz konusu yolculukların önemli bir kısmının rekreatif amaçlı olması üzerinden açılanabilir. Her ne kadar söz konusu savların desteklenmesi, her bir ulaşım türü için erişilebilirlik düzeyleri ile birlikte başlangıç ve bitiş noktaları bilgileri ile tekrar analiz edilmeye muhtaç olsa da, söz konusu savin arka planında yolculuk amaçlarının yolculuk türleri itibariyle farklı dağılımlar sergi- 
leyebileceği hususunun yer aldığı açıkça ifade edilebilir. Gelecekteki potansiyel çalışmalar, bu sava yönelik yeni veri setleri üzerinden yürütülebilir.

Son olarak, deneysel bulgular ışığında İstanbul örneği üzerinden ortaya konulan söz konusu toplu taşıma türlerine yönelik kullanım oranlarındaki bariz azalış eğilimlerinin önümüzdeki süreçlerde kalıcı olması beklenmemekle beraber geri dönüş etkisinin ne zaman başlayıp bu türlerin eski kullanım oranlarına ne zaman döneceği bilinememektedir. Bu veriler önümüzdeki bir kaç yıl daha takip edilerek pandeminin İstanbul ulaşımında ne zaman etkisini kaybedeceği gözlemlenebilir. 


\section{Extended Abstract}

\section{Measuring the Effect of Pandemic on Public Transportation Modes: Multinominal Logit Model in İstanbul}

Enver Cenan İnce
ORCID: 0000-0002-8264-6707

\author{
Elif Can Cengiz \\ ORCID: 0000-0002-7720-5966
}

\author{
Pelin Alpkökin \\ ORCID: 0000-0002-9612-2023
}

The COVID epidemic has rapidly affected all the World with especially the effect of increasing globalization processes resulting in rapidly increasing passenger flows in urban areas. This has caused rigid precautions of minimizing the passenger flows as much as possible, which has resulted in dramatic changes especially in the modal split ratios of the motorized flows in urban areas in all over the World. In this sense, it has been required to measure the changing trends in the amounts of the modal split ratios with especially regard to the public transportation facilities so as to overcome the current preliminary transportation problems that has been caused by the pandemic process in urban areas. That is to say, the precautions of the pandemic process have resulted in the investigations on the changes of basic requirements of the urban communities with especially regard to the imperative urban motorized flows called home based work trips and home based imperative shopping trips, which are carried out by urban public transportation facilities. From this point forth, it has been empirically measured the effect of pandemic process on the modal split ratios in the case of İstanbul in this research with the help of the Multinominal Logit (MNL) model that has been conducted by the daily trip data of June 2019, July 2020, and May 2021 in İstanbul. Hence, the decrease in the usage of the public transportation modes -with regard to the common belief indicating that the pandemic virus generally sprawls in the public transport modes with high passenger carriage capacities- has extensively begun to be interrogated in this research. 
There have been defined two main variables called daily trip records of the passengers per six public transportation modes (bus, metrobus, metro, light rail systems, Marmaray, and sea transport) and daily number of COVID cases per one hundred thousand people in İstanbul. Herein, the trip data of June 2019, July 2020, and May 2021 were published by the İstanbul Metropolitan Municipality (IMM, 2019; 2020; 2021), while the daily number of COVID cases per one hundred heads in the related dates (June 2019, July 2020, and May 2021) in İstanbul were published by the Ministry of Health of the Turkish Republic. The daily trip records per each public transportation mode were categorized by five different demand threshold values. Herein, the range -constituted by the minimum demand value for bus mode that is equal to 259,043 and the maximum demand value for the bus mode that is equal to 3,311,249- was divided by five classes with equal intervals. The same procedure was also implemented for each transportation mode called metrobus, metro, light rail systems, Marmaray, and sea transport with regard to their minimum and maximum daily trip records. Hereby, the effect of the daily number of COVID cases per one hundred thousand heads on the daily modal split ratios of bus, metrobus, metro, light rail systems, Marmaray, and sea transport has been empirically measured with the help of the Multinominal Logit (MNL) model in the case of İstanbul.

According to the observations, the prominent decrease in the pandemic process was observed in the usage of sea transport mode with the average decreasing ratio that is equal to $75.81 \%$ in the case of İstanbul. This average decreasing ratio was followed by the light rail systems, Marmaray, metro, bus, and metrobus that are respectively equal to $70 \%, 66.67 \%, 60 \%, 56.67$ $\%$, and $50 \%$ in the case of İstanbul. In addition, the most dramatic decreasing ratio that is equal to $43 \%$ was estimated again for sea transportation mode with regard to the marginal effects of the daily number of COVID cases on the modal split ratios for six transportation modes according to the results of the MNL model. This estimated decreasing ratio was followed by Marmaray, light rail systems, metrobus, and metro with the ratios that are respectively equal to $32.84 \%, 32.80 \%, 25 \%, 25 \%$, and $24.88 \%$ according to the results of the MNL model in the case of İstanbul. In other words, the decrease -changing in between $24 \%$ and $43 \%$ in the usage of the public transportation modes called bus, metrobus, metro, light rail systems, Marmaray, and sea transport- was observed.

Also, it was seen that the related decreasing ratios got larger as the passenger carrying capacities of the public transit mode increased. Herein, it is 
interesting that the estimated decreasing ratio with the effect of the daily COVID counts for sea transportation mode is almost twofold when compared to the related decreasing ratios of bus and metrobus modes in the case of İstanbul. This would have been caused by the precautions that are officially implemented by the government on the related dates of the pandemic process. Herein, the gradual flexibility in the closure of the official working areas in addition to the inclination of minimizing the recreational trips would have caused that the least affected modes are metrobus and bus, while the most affected mode is sea transport within the pandemic process especially since the beginnings of the summer season in 2020 in the case of İstanbul. This would have been the case due to the fact that most of the home based work trips are inclined to be carried out by bus and metrobus, while the daily recreational trips are inclined to be exhibited by sea transport mode in İstanbul. These empirical hypotheses should be tested more with the help of the daily trip counts that are recorded by their origins and destinations in the related future studies.

\section{Kaynakça/References}

Amelang, S. (2020, Mayıs 07). Pandemic makes private cars more popular, public transport loses out- survey. Clean Enery Wire. 10 Ağustos 2021 tarihinde https://www.cleanenergywire.org/news/pandemic-makes-private-cars-morepopular-public-transport-loses-out-survey adresinden erişildi.

Amerika'nın Sesi. (2020, Eylül 09). İstanbul Valiliği yeni corona virüs önlemlerini açıkladı. $11 \quad$ Ağustos $2021 \quad$ tarihinde https://www.amerikaninsesi.com/a/istanbul-da-valilik--corona-virususalginina-karsi-yeni-onlemleri-acikladi/5576497.html adresinden erişildi.

Apple. (2021, Ağustos 12). Hareketlilik trendleri. 12 Ağustos 2021 tarihinde https://covid19.apple.com/mobility adresinden erişildi.

Bernhardt, J. (2020, Mart 25). Decline in ridership, adapted timetables and disinfection-robots-the impact of Corona/ Covid 10 on public transport. Urban Transport Magazine. 10 Ağustos 2021 tarihinde https://www.urban-transportmagazine.com/en/decline-in-ridership-adapted-timetables-and-disinfectionrobots-the-impact-of-corona-covid-10-on-public-transport/ adresinden erişildi.

Cameron, C., ve Trivedi, P. (2005). Microeconometrics: Methods and Applications. New York: Cambridge University Press.

Carteni, A., Di Francesco, L., ve Martino, M. (2020, Kasim 1). How mobility habits influenced the spread of the COVID-19 pandemic: Results from the Italian case study, Science of the Total Environment, 741. 
Christidis, P., Christodoulou, A., Navajas-Cawood, E., ve Ciuffo, B. (2021). The postpandemic recovery of transport activity: Emerging mobility patterns and repercussion on future evolution. Sustainability, 13.

DSÖ. (2020, Nisan 27). Archived: WHO timeline-COVID-19. 12 Ağustos 2021 tarihinde https://www.who.int/news/item/27-04-2020-who-timeline---covid-19 adresinden erişildi.

Eken, Ö., Tosun, N., ve Eken, D. T. (2020, 10 14). Covid-19 salgını ile acil ve zorunlu uzaktan eğitime geçiş: Genel bir değerlendirme. Milli Ĕ̆itim, 113-128.

El-Habil, A. (2012). An application on multinominal logistic regression model. Journal of Statistics and Operation Research.

Erbaş, Ö. (2020, Nisan 04). COVID-19 döneminde kent içi toplu ulaşım kullancı davranışları: İstanbul örneği. Kent Akademisi, 13, 431-442.

Falchetta, G., ve Noussan, M. (2020). The impact of COVID-19 on transport demand, modal choices, and sectoral energy consumption in Europe. The Energy Journal, 48-50.

Gümüş, A. ve Hacıevliyagil, N. (2020). Covid-19 salgın hastalığının borsaya etkisi: Turizm ve ulaşım endeksleri üzerine bir uygulama. Akademik Yaklaşımlar Dergisi, 76-98.

İBB. (2019-2020-2021). İstanbul ulaşım ve hareketlilik raporu.

İBB Açık Veri Portalı. (2021, Ekim 01) Trafik indeks veri seti

London Assembly. (2020, Ekim 15). Changes in London road traffic since March 2020. $10 \quad$ Ağustos 2021 tarihinde https://www.london.gov.uk/questions/2020/3301 adresinden erişildi.

Sinko, S., Prah, K., ve Kramberger, T. (2021, Haziran 24). Spatial modelling of modal shift due to COVID-19, Sustainability, 13.

Tavukçu, S. (2020, Nisan 10). Salgın hastalıkların tetiklediği dünya tarihindeki güç ve düzen değişiklikleri. 23 Eylül 2021 tarihinde https://www.sde.org.tr/sinantavukcu/genel/salgin-hastaliklarin-tetikledigi-dunya-tarihindeki-guc-veduzen-degisiklikleri-kose-yazisi-16688 adresinden erişildi.

TC. Sağlık Bakanlığı. (2021, Ağustos 10). Genel koronavirüs tablosu 10 Ağustos, 2021 tarihinde https://covid19.saglik.gov.tr/TR-66935/genel-koronavirustablosu.html adresinden erişildi.

Tosman, Ö. (2021, Ağustos 15). İstanbul ulaşımına COVID-19 etkisi. 15 Ağustos 2021 tarihinde http://cushbakisi.com/blog/istanbul-ulasimina-covid-19-etkisi/ adresinden erişildi.

TÜBİTAK. (2021, Ağustos 13). Türkiye'de durum. 13 Ağustos 2021 tarihinde https://covid19.tubitak.gov.tr/turkiyede-durum adresinden alındı

TÜİK. (2020). 15 Ağustos 2021 tarihinde erişildi.

Worldometer. (2021, Ağustos 12). COVID-19 coronavirus pandemic 12 Ağustos 2021 tarihinde https://www.worldometers.info/coronavirus/\#countries adresinden erişildi. 